\title{
Artikel
}

\section{De kwetsbare legitimaris, de langstlevende partner en de kantonrechter}

Mr. dr. J.H.M. ter Haar en mr. G.A. Tuinstra*

\section{Inleiding}

In de erfrechtelijke praktijk komt het geregeld voor dat een erflater zowel een langstlevende partner achterlaat als een kind dat binnen de categorie 'kwetsbare personen' valt. Hiermee doelen we op minderjarigen, maar ook op personen die onder curatele staan of van wie het vermogen onder een meerderjarigenbewind is gesteld. Degene die het bewind voert (ouder, voogd, curator, bewindvoerder), dient de belangen van het kwetsbare kind zorgvuldig te behartigen. Het is an de kantonrechter om toezicht op dit bewind te houden. Recentelijk kwamen uitspraken voorbij waarin de erfrechtelijke belangen van de langstlevende partner en een kwetsbaar kind botsten, de kantonrechter machtiging werd verzocht en de legitieme portie steeds impliciet of expliciet een rol speelde. Hoe gaat de toezichthoudende rechter in deze gevallen om met een schending van de legitieme? We staan hieronder stil bij een aantal sprekende voorbeelden en bezien hoe de kantonrechter (sinds 2003) zoal omgaat of om zou moeten gaan met het belang van de kwetsbare legitimaris.
Mr. dr. J.H.M. ter Haar is universitair docent Notarieel recht aan de Rijksuniversiteit Groningen. Mw. mr. G.A. Tuinstra is docent Notarieel recht aan de Rijksuniversiteit Groningen.

\section{Bescherming van de langstlevende partner}

Sinds 1 januari 2003 genieten de langstlevende echtgenoot en geregistreerde partner in het erfrecht een hoge mate van bescherming. Deze bescherming vinden we terug in de regeling van de wettelijke verdeling (art. 4:13 e.v. van het Burgerlijk Wetboek (BW)), de beperkingen in de opeisbaarheid van de legitieme portie (onder andere art. 4:81 en 4:82 $\mathrm{BW}^{1}$ ) en in de andere wettelijke rechten (art. 4:28, 4:29 en 4:30 BW). De bescherming is erop gericht dat de langstlevende kan voortleven als voorheen en in ieder geval een vangnet heeft voor het geval hij/zij door de eerststervende op onvoldoende wijze is bedeeld om in het eigen levensonderhoud te voorzien. Boek 4 BW faciliteert ook de bescherming van de ongehuwde partner, met name in artikel 4:82 BW.

De niet-opeisbaarheid van de aanspraken van de kinderen op de langstlevende zorgt ervoor dat zij meestal in een levenslange onderlinge rechtsverhouding verkeren. De defiscalisering van de schulden en vorderingen in de Wet inkomstenbelasting 2001 en het door de langstlevende verplicht voorschieten van de door de kinderen verschuldigde erfbelasting dragen eraan bij dat dit besef vaak niet bij de betrokkenen aanwezig is. Het is reden te meer voor de wettelijke vertegenwoordiger om de aanspraken van het kwetsbare kind correct vast te leggen. Anders kunnen zich bij het overlijden van de langstlevende gemakkelijk discussies voordoen, met name als de erfgenamen van de langstlevende niet dezelfde zijn als die van de eerststervende.

1. Zie ook art. 129 en art. 131 Overgangswet nieuw BW 


\section{Personae miserabiles}

Het erfrecht kent verschillende bepalingen die de belangen van de kwetsbare persoon beogen te waarborgen. Zo kan aanvaarding als erfgenaam slechts beneficiair en is verwerpen zonder machtiging van de kantonrechter niet mogelijk (art. 4:193 lid 1 en 1:441 lid 5 BW). De voogd en de curator van een kwetsbaar kind moeten een boedelbeschrijving van een verkrijging krachtens erfrecht of gift $^{2}$ door het kind indienen bij de rechtbank (art. 1:386 en 1:342 lid 1 jo. art. 1:338 lid 3 BW). Voor de meerderjarigenbewindvoerder blijkt een dergelijke verplichting niet uit de wet. ${ }^{3}$ Het spreekt voor zich dat een erfrechtelijke verkrijging of gift wel bij de periodieke rekening en verantwoording door de bewindvoerder naar voren wordt gebracht. ${ }^{4}$ De ouder is niet verplicht een boedelbeschrijving in te dienen of anderszins de kantonrechter van een verkrijging krachtens erfrecht of gift door de minderjarige op de hoogte te stellen. Op de ouder zijn de bepalingen van het voogdijbewind ingevolge artikel 1:253k BW slechts beperkt van toepassing. ${ }^{5}$

Is sprake van de wettelijke verdeling als bedoeld in artikel 4:13 BW, dan moet iedere wettelijke vertegenwoordiger - onder wie dus ook de ouder - binnen een jaar na het overlijden een boedelbeschrijving van de nalatenschap indienen bij de rechtbank (art. 4:16 lid $2 \mathrm{BW}$ ). Is sprake van een wilsrecht in de zin van artikel 4:19 t/m 4:22 BW, dan dient de wettelijke vertegenwoordiger zijn voornemen omtrent de uitoefening van dat recht ter goedkeuring aan de kantonrechter voor te leggen (art. 4:26 lid $1 \mathrm{BW}$ ). Opmerkelijk is dat voor het inroepen van de legitieme portie - eveneens een wilsrecht Boek 4 BW geen specifieke waarborg kent. ${ }^{6}$ Het spreekt voor zich dat de wettelijke vertegenwoordiger, die goed bewind moet voeren, schending van de legitieme portie niet mag negeren. Doet hij dit wel, dan vervalt het recht

2. Art. 1:342 BW spreekt ten onrechte nog steeds van 'schenking' omdat de wettekst bij invoering van de huidige titel 'Schenking' (titel 7.3 BW) niet is aangepast.

3. De plicht om een boedelbeschrijving in te dienen, lijkt alleen bij aanvang van het bewind te gelden (art. 1:436 lid 1 BW).

4. Dit blijkt voor wat de verkrijging van de rechthebbende als erfgenaam betreft in ieder geval uit het bepaalde in de Aanbevelingen Meerderjarigenbewind van het LOVCK\&T (2018) onder E7.

5. Sinds 2 november 1995 is na overlijden van één van de ouders van een minderjarig kind de overgebleven ouder geen voogd meer, maar blijft hij ouder, zodat sindsdien ook op zijn bewind een beperkt regime van toezicht geldt. Het is onduidelijk of de wetgever zich gerealiseerd heeft dat de wijziging in het gezagsrecht belangrijke gevolgen had voor de waarborgen met betrekking tot de erfrechtelijke aanspraken van het minderjarige kind (zie J.H.M. ter Haar, Minderjarigen en (de zorg voor hun) vermogen (diss. Groningen), Den Haag: Boom Juridische uitgevers 2013, p. 217 en 218)

6. Zie Ter Haar, Minderjarigen en (de zorg voor hun) vermogen, p. 223-224. Zie over (het ontbreken van) waarborgen voor de minderjarigen en suggesties voor verbetering J.H.M. ter Haar, W.D. Kolkman, W.M. Schrama \& L.C.A. Verstappen, Toezicht op het bewind van ouders en voogden over het vermogen van minderjarigen, Den Haag: Boom juridisch 2017. De onderzoekers pleiten wat erfrechtelijke aanspraken van minderjarigen betreft voor meer actief kantonrechterlijk toezicht op het moment van de verkrijging, zie p. 219-222. De Minister voor Rechtsbescherming heeft naar aanleiding van dit WODC-rapport een conceptwetsontwerp aangekondigd. op de legitieme portie vijf jaar na overlijden van de erflater (art. 4:85 BW) en kan de wettelijke vertegenwoordiger aansprakelijk zijn wegens slecht bewind.

In het kader van goed bewind verdient het aanbeveling de erfrechtelijke vordering van het kwetsbare kind op de langstlevende partner vast te stellen. Dit vereist ingevolge het bekende arrest Erven van der Kammen ${ }^{7}$ bij minderjarigheid of curatele de machtiging van de kantonrechter in de zin van artikel 1:345 lid 1 sub a BW (jo. art. 1:253k respectievelijk art. 1:386 lid $1 \mathrm{BW}$ ). Bij het meerderjarigenbewind geldt hetzelfde indien de rechthebbende niet in staat is of weigerachtig is om zelf toestemming voor de vaststelling van de vordering te geven (art. 1:441 lid $2 \mathrm{BW}$ ).

Zoals in de inleiding anngekondigd, staan we hieronder stil bij een selectie van uitspraken in het kader van de kwetsbare legitimaris. We onderscheiden daarbij twee situaties. De eerste (par. 4) betreft het geval dat machtiging wordt verzocht voor het vaststellen van de erfrechtelijke (niet-legitimaire) vordering van een kind, terwijl ondertussen zijn legitieme is geschonden. In de tweede situatie (par. 5) wordt machtiging gevraagd voor het berusten in de schending van de legitieme. De kantonrechter staat in deze laatste situatie pal voor de legitieme, in de eerste situatie niet altijd. De vraag is of dat laatste terecht is.

\section{Machtiging voor vaststellen vordering kind}

\subsection{Rb. Rotterdam 17 februari 2020, ECII:NL:RBROT:2020:1352}

Erflater overlijdt in 2018 met achterlating van zijn ongehuwde levenspartner en hun minderjarige kind (zeven of acht jaar oud). Erflater heeft zijn levenspartner voor $1 / 100$ tot erfgenaam benoemd en zijn kind voor de rest. De levenspartner is executeur en afwikkelingsbewindvoerder onder de last de nalatenschap te verdelen als ware er een wettelijke verdeling als bedoeld in artikel 4:13 BW. Men spreekt in de praktijk ook wel van een quasi-wettelijke verdeling. In de uiterste wil is ook een zogenaamd afvullegaat opgenomen. De langstlevende krijgt daarmee (ter keuze) een extra geldlegaat, normaliter bedoeld om de erfbelasting te beperken of te voorkomen. In dit geval lijkt het erop dat erflater met het afvullegaat zijn partner de mogelijkheid heeft gegeven om de (fiscale) verkriiging van het kind te beperken tot (minimaal) zijn vrijstelling voor de erfbelasting, zodat zij over het erfdeel van het kind geen erfbelasting hoeft voor te schieten. Het saldo van de nalatenschap bedraagt in casu $€$ 203.019. De kantonrechter verleent machtiging voor vaststelling van de vordering op

7. HR 9 september 1988, ECLI:NL:HR:1988:AC1018, NJ 1989/239 m.nt. W.M. Kleijn. 
$€ 20.363,31$, net een onsje minder dan de kindvrijstelling (2018: € 20.371).

Terecht wordt door B.M.E.M. Schols opgemerkt dat voor de verdeling door de afwikkelingsbewindvoerder - die daartoe op grond van het testament de zelfstandige bevoegdheid heeft - de kantonrechterlijke goedkeuring van artikel 3:183 lid $2 \mathrm{BW}$ niet is vereist. ${ }^{8}$ Het gaat hier echter om vaststelling van de vordering, zoals hiervoor al aangegeven een mogelijk prijsgeven van rechten, waarvoor op grond van artikel 1:345 lid 1 sub a BW machtiging nodig is. De kantonrechter overweegt daarover als volgt:

\section{'3.3.}

De kantonrechter acht bij de beoordeling van het verzoek grote terughoudendheid op zijn plaats, om zoveel mogelijk te voorkomen dat het door erflater met het testament beoogde doel door rechterlijke inmenging niet kan worden verwezenlijkt. Uit de 'Considerans' en de overige onder 2.6 tot en met 2.9. genoemde onderdelen van het testament blijkt de duidelijke bedoeling van erflater om de belangen van verzoekster voorop te stellen door haar na zijn overlijden ongestoord te laten voortleven. Hij heeft haar daartoe ruime bevoegdheden toegekend om, indien gewenst, enig gerechtigde te worden van de goederen van zijn nalatenschap. Zo heeft hij haar de testamentaire last opgelegd om de nalatenschap te verdelen als mare er een wettelijke verdeling en inhoudelijk overeenkomend met de wettelijke verdeling als bedoeld in artikel 4:13 BW. De erfrechtelijke positie van zijn zoon [minderjarige] is daarbij ondergeschikt aan die van verzoekster, zijn langstlevende partner.

3.4 .

Voor de kantonrechter staat voorop dat het testament van erflater verzoekster het recht geeft om in beginsel vrij te beschikken over de nalatenschap om ongestoord te kunnen voortleven na het overlijden van erflater. Deze testamentaire bevoegdheid om vrij te kunnen beschikken over de nalatenschap wordt slechts begrensd bij misbruik van die bevoegdheid. Daarvan is niet gebleken.

Gelet op het voorstaande zal daarom de gevraagde machtiging worden verleend.'

Uit de beschikking valt overigens niet op te maken hoe de vordering van het kind is berekend. We nemen aan dat de niet-opeisbare vordering een samengestelde rente van jaarlijks $6 \%$ draagt, zodat de contante waarde van de vastgestelde vordering gelijk is aan $€ 20.363,31 .{ }^{9}$ Wordt geen of een lagere rente gerekend, dan is de contante waarde van de vordering, zeker nu aannemelijk is dat de langstlevende partner relatief jong is, mogelijk fors lager dan de nominale waarde.

8. B.M.E.M. Schols, De minderjarige, de notaris en de kantonrechter. Terughoudend, doch afgevuld, EstateTip Review 2020/23.

9. Deze rente komt overeen met de rekenrente voor het fictieve vruchtgebruik van de langstlevende partner, art. 21 lid 14 SW 1956 jo. art. 5 en 10 Uitvoeringsbesluit SW 1956.
- Schending legitieme en taak kantonrechter

Opvallend is dat de kantonrechter geen expliciete overweging wijdt aan de legitieme portie van het kind. Deze bedraagt immers in elk geval de helft van de nalatenschap, te weten de helft van $€ 203.019$ of $€ 101.509,50$. Hoewel dit niet uit de uitspraak blijkt, is aannemelijk dat het testament een clausule bevat in de zin van artikel 4:82 $\mathrm{BW},{ }^{10}$ zodat de legitieme portie van het kind pas opeisbaar is als de langstlevende overlijdt en diens verzorging in beginsel niet in het geding is. Een legitimaris-erfgenaam kan zijn erfdeel verwerpen en daarbij gelijktijdig zijn legitieme portie inroepen (art. 4:63 BW). Deze route kent het risico van imputatie (art. 4:72 BW) en het gemis aan oprenting (behoudens de inflatiecorrectie van art. 4:84 $\mathrm{BW}$ ). In de onderhavige casus heeft het kind al beneficiair aanvaard, zodat verwerping sowieso geen optie meer is. De mogelijkheid van een aanvullend beroep op de legitieme portie dringt zich daarentegen mel op.

Moet de kantonrechter de legitieme portie van het kind in zijn beschikking betrekken? Hem wordt uiteindelijk slechts verzocht machtiging te verlenen voor de vaststelling van de vordering conform de uiterste wil. B.M.E.M. Schols suggereert dat dit niet het geval is als hij in EstateTip Review 2020/23 schrijft:

'(...) blijkbaar is (nog) geen beroep gedaan op de legitieme portie. Daar gaat de wettelijk vertegenwoordiger over. Ofwel, daar bemoeit de kantonrechter zich in eerste instantie niet mee.'

Wij pleiten ervoor dat de kantonrechter zich mel ongevraagd met de legitieme portie van kwetsbare kinderen bemoeit. De taak van de kantonrechter als toezichthouder is immers het waarborgen van de vermogensrechtelijke belangen van kwetsbare personen. In de gevallen waarin hij voortdurend toezicht houdt op het vermogensbeheer, zoals bij curatele, meerderjarigenbewind en voogdij, is dit volkomen duidelijk. Maar ook als hij incidenteel toezicht houdt, zoals bij het bewind van ouders, als hem om machtiging wordt verzocht, is het zijn taak verder te kijken dan alleen het machtigingsverzoek. Hij heeft niet voor niets allerhande mogelijkheden om in het belang van de kwetsbare persoon ambtshalve op te treden. ${ }^{11}$ Juist omdat het schenden van de legitieme portie van een kwetsbaar kind in de praktijk gemakkelijk onzichtbaar blijft, zeker sinds het verdwijnen van de goederenrechtelijke legitieme in 2003, zou de kantonrechter hierop scherp moeten letten. Sinds 2003 noodzaakt de goederenrechtelijke afwikkeling van de nalatenschap immers niet meer tot een expliciete keuze van of namens de legitimaris. Het is in de Rotterdamse casus

10. Het ontbreken van een dergelijke clausule zou zelfs aansprakelijkheid van de notaris met zich kunnen brengen, zie HR 19 februari 2016, ECLI:NL:HR:2016:288, NJ 2016/295.

11. Zo kan hij onder andere ambtshalve ouders ten verhore oproepen (art. 1:354 BW), kan hij een bijzondere curator benoemen om de belangen van de minderjarige waar te nemen (art. 1:250 BW), en kan hij zelfs een bewindvoerder benoemen die in plaats van de ouders het bewind over het vermogen van de minderjarige voert (art. 1:370 BW). 
evident dat de belangen van de langstlevende partner en die van de minderjarige tegenstrijdig zijn. Dit vergt een alerte en kritische houding van de kantonrechter.

Het vaststellen van een vordering impliceert mogelijk een prijsgeven van rechten. Impliceert de enkele vaststelling dan ook dat het recht op de legitieme portie wordt prijsgegeven? Met Schols menen wij dat dit niet het geval is. Maar constateert de kantonrechter bij de behandeling van het verzoek een mogelijke schending van de legitieme, dan dient hij hiervoor aandacht te hebben in zijn beschikking en de motivering daarvan. Hij kan in zo'n geval niet doen alsof zijn neus bloedt. Dat de langstlevende als testamentair begunstigde geen misbruik van bevoegdheid makt, betekent nog niet dat de legitieme portie van het kind onbenoemd kan blijven.

\section{- Het belang van het kind als eerste overmeging}

De kantonrechter laat de legitieme portie in casu onbenoemd, maar wekt wel sterk de indruk zich van de wettelijke aanspraak van het kind bewust te zijn. Waarom lezen wij anders in zijn overwegingen zoveel respectbetuigingen voor de testeervrijheid van de erflater?

Het is opvallend dat de kantonrechter zich bij de motivering van zijn beschikking vooral sterk maakt voor het door de erflater met het testament beoogde doel: het ongestoord voortleven van de langstlevende partner. Dat hoeft de kantonrechter helemaal niet te doen, daar heeft de wetgever immers al ruimschoots voor gezorgd door toe te staan dat de legitieme portie van het kind niet opeisbaar is. De kantonrechter heeft hierbij geen enkele taak.

Ingevolge artikel 3 van het Internationaal Verdrag inzake de Rechten van het Kind (Trb. 1990, 170) vormen bij alle maatregelen betreffende kinderen de belangen van het kind de eerste overweging. In overeenstemming hiermee vloeit uit artikel 1:356 BW voort dat de kantonrechter zijn machtigingen slechts geeft 'indien dit hem in het belang van de minderjarige noodzakelijk, nuttig of wenselijk blijkt te zijn'. Het is daarom op zijn minst genomen wonderlijk dat aan het belang van het kind in deze beschikking geen enkele overweging is gewijd. Zorgvuldigheid is geboden. Uit een uitspraak van het Europees Hof voor de Rechten van de Mens (EHRM) (S.L. en J.L./Kroatië; een flat voor een villa) blijkt dat nalatigheid van de toezichthouder strijd kan opleveren met artikel 1 Eerste Protocol bij het Europees Verdrag tot bescherming van de rechten van de mens en de fundamentele vrijheden (EVRM), omdat de staat daarmee faalt in het daadwerkelijk beschermen van zijn vermogensrechtelijke belangen. ${ }^{12}$ Het wegkijken bij een klaar-

12. EHRM 7 mei 2015, ECLI:NL:XX:2015:325, NJ 2016/253 m.nt. L.C.A. Verstappen (S.L. en J.L./Kroatië, een flat voor een villa). De toezichthouder deed onvoldoende onderzoek naar de belangen van de minderjarigen in het kader van een verzoek tot machtiging voor de overeenkomst waarin een villa die eigendom was van de kinderen voor een flat werd geruild. Zie hierover ook Asser/De Boer, Kolkman \& Salomons 1-I 2020/456 en eerdergenoemd WODC-rapport: Ter Haar e.a., Toezicht op het bewind van ouders en voogden over het vermogen van minderjarigen, p. 24-28. blijkelijke schending van de legitieme portie van een minderjarige zou een dergelijke schending van Europees recht kunnen zijn.

\subsection{Hof Amsterdam 11 mei 2006, ECLI:NL:GHAMS:2006:AX1177}

In deze Amsterdamse casus staat het vermogen van een verstandelijk gehandicapt kind onder meerderjarigenbewind. De bewindvoerder is de broer van het kind. Hun vader is in 2003 overleden. Hij heeft in zijn ouderlijke boedelverdelingstestament zijn echtgenote en zijn kinderen tot erfgenamen benoemd en het erfdeel van het gehandicapte kind beperkt tot 4/100 van het versterferfdeel. Vader heeft het resterende 96/100 deel in geld gelegateerd aan de andere kinderen, onder de last om daaruit aan hun gehandicapte zuster uitkeringen te doen zo vaak en zoveel als haar wettelijke vertegenwoordiger dat nodig acht. De broer vraagt als bewindvoerder machtiging voor het vaststellen van de vordering van zijn gehandicapte zuster ingevolge de ouderlijke boedelverdeling. De kantonrechter heeft de machtiging geweigerd, omdat de zuster door de erfstelling in het testament beduidend minder ontvangt dan haar legitieme portie. In hoger beroep oordeelt het hof, voor zover relevant, als volgt (r.o. 4.4):

'Anders dan de kantonrechter is het hof van oordeel dat de mogelijkheden van rechthebbende om een beroep te doen op de legitieme portie door de conceptakte vaststelling ouderlijke boedelverdeling niet worden beperkt, nu zij ook na vaststelling van de ouderlijke boedelverdeling nog een beroep op haar legitieme portie zal kunnen doen zoals in de wet is bepaald. Bij de beslissing om een beroep te doen op de legitieme portie zou zich ten aanzien van de bewindvoerder een belangenverstrengeling kunnen voordoen, onder meer nu de bewindvoerder tevens erfgenaam is en hetgeen hem op grond van het legaat toekomt door instelling van deze vordering ook verminderd zou worden. In dit verband overweegt het hof dat - mede gelet op hetgeen ter terechtzitting in hoger beroep door de bewindvoerder is verklaard en de inhoud van de conceptakte - niet is gebleken van een zodanige belangenverstrengeling dat rechthebbende hierdoor nadeel zal ondervinden, in die zin dat zij minder zal ontvangen dan zij gelet op haar goede verzorging nodig heeft. Het hof zal de beschikking waarvan beroep derhalve vernietigen en de machtiging verlenen.'

Evenals de Rotterdamse kantonrechter geeft het Amsterdamse hof onvoorwaardelijk machtiging voor de vaststelling van de vordering van het kwetsbare kind, wiens legitieme terloops wordt geschonden. Een wezenlijk verschil is dat het hof - overigens gedwongen door de rechter in eerste aanleg - expliciet oog heeft voor de schending van de legitieme. Het hof vertrouwt, mede gelet op de lastbevoordeling in het testament, kennelijk op een goede verzorging van de dochter en constateert dat de vaststelling van de vordering een later beroep op 
de legitieme niet uitsluit. Een ander verschil is dat in de Amsterdamse casus de broer als bewindvoerder onder voortdurend toezicht van de kantonrechter staat. Deze kan de broer aansporen om de legitieme portie alsnog in te roepen en hem zelfs ambtshalve tot schadevergoeding veroordelen (art. 1:445 lid 5 jo. art. 1:362 BW). In de Rotterdamse zaak laat de kantonrechter de legitieme portie onbenoemd, in de wetenschap dat er geen voortdurend toezicht zal zijn op het bewind van de ouder, waardoor de belangen van de minderjarige verre van gewaarborgd zijn.

\subsection{Een handreiking}

Als gezegd, de kantonrechter mag naar onze mening niet wegkijken als hem machtiging wordt verzocht voor het vaststellen van een erfrechtelijke vordering van een kwetsbaar kind, terwijl hij terloops constateert dat de legitieme portie is geschonden. De Amsterdamse rechters wijden terecht overwegingen aan de legitieme. Bij de Rotterdamse kantonrechter blijft de legitieme ten onrechte de spreekwoordelijke 'roze olifant in de kamer'.

Men zou de situatie kunnen vergelijken met die waarin de kantonrechter verzocht wordt om machtiging voor de vaststelling van een vordering bij de wettelijke verdeling, terwijl hij terloops constateert dat sprake is van een wilsrecht in de zin van artikel 4:19 t/m 4:22 BW. De kantonrechter zal dan in het belang van het kind oog moeten hebben voor de verplichting van de wettelijke vertegenwoordiger om zijn voornemen omtrent de uitoefening van het wilsrecht kenbaar te maken (art. 4:26 lid $1 \mathrm{BW})$. Een vergelijkbare verplichting ontbreekt opmerkelijk genoeg voor het wilsrecht van de legitieme. Maar dit betekent niet dat de kantonrechter zich het belang van het kind bij zijn legitieme niet ambtshalve hoeft aan te trekken.

Hiermee beweren we niet dat de Rotterdamse kantonrechter de langstlevende ouder per se had moeten dwingen tot een beroep op de legitieme. Wel had hij de legitieme moeten aankaarten. Zo had de kantonrechter aan de verzochte machtiging bijvoorbeeld de voorwaarde kunnen verbinden dat de langstlevende zou terugkomen voor machtiging voor het vaststellen van de legitimaire vordering of voor het berusten in de schending van de legitieme. De kantonrechter kan immers aan de machtiging de voorwaarden verbinden die hem goeddunken (art. 1:356 BW). Komt de langstlevende ouder door het inroepen van de legitieme portie in financiële problemen vanwege zijn plicht de erfbelasting hierover voor te schieten (art. 4:88 BW), dan kan dat indirect ten nadele van het kind zijn. Meent de kantonrechter dat dit berusting rechtvaardigt, dan is de afweging in elk geval inzichtelijk. ${ }^{13}$

13. Het is ook denkbaar dat de kantonrechter juist te 'ijverig' is in het waarborgen van de belangen van de kinderen. Zo gaf de rechtbank Middelburg (8 december 2008, ECLI:NL:RBMID:2008:BI0224) machtiging aan een langstlevende partner, tevens moeder van de minderjarige kinderen van de erflater, voor vaststelling van de niet-opeisbare legitieme porties, zeker gesteld door een tweede hypotheek op haar huis.

\section{Machtiging voor berusten in schending legitieme}

Schending van de legitieme kent vele gedaanten. Volledige uitsluiting van de nalatenschap is een daarvan. Dit gebeurt niet zelden bij (meerderjarige) verstandelijk gehandicapte kinderen. ${ }^{14}$ Het kind zelf kan rekenen op overheidssteun en de nalatenschap zal aan deze steun in de weg kunnen staan omdat het kind ineens als vermogend wordt aangemerkt. Curatoren of bewindvoerders, veelal de ouders van het kind, hebben in dat geval liever dat de nalatenschap vererft aan bijvoorbeeld de andere kinderen, ook om dure dubbele vererving te voorkomen. In de twee navolgende beschikkingen, waarin steeds sprake is van een legitieme portie als niet-opeisbare vordering op de langstlevende partner van de erflater, wil de rechter in beginsel echter niets weten van berusting in de onterving.

\subsection{Rb. Midden-Nederland 18 januari 2018, ECII:NL:RBMNE:2018:127}

De vader van een onder curatele gestelde is in 2016 overleden, met achterlating van zijn echtgenote en hun drie kinderen. Erflater heeft zijn gehandicapte dochter onterfd en de curator (de langstlevende) verzoekt de kantonrechter machtiging om in de onterving te berusten. De dochter zou door het inroepen van haar nietopeisbare legitieme portie (een bedrag van $€ 20.000$ ) niet meer in aanmerking komen voor onder andere zorgtoeslag en huurtoeslag, terwijl het belang van de curanda zou zijn om aanspraak te behouden op dit soort toeslagen, aldus de curator. De kantonrechter wijst het verzoek ons inziens terecht af, maar betrekt daarbij onder 3.2 ten onrechte het algemeen belang:

'Het door de curator gestelde belang dient afgewogen te worden tegen het algemeen belang om gemeenschappelijke voorzieningen in te zetten voor die personen in de samenleving die daar daadwerkelijk behoefte aan hebben en geen andere financiële mogelijkheden hebben. In die belangenafweging dient het algemeen belang zwaarder te wegen dan het individuele belang van curanda. Curanda heeft recht op een bepaald vermogen en mag daar, ten nadele van het algemeen belang, niet van afzien.'

De wet gebiedt geen zekerheidstelling in zo'n geval, maar toch ging de kantonrechter mee in dit aanbod van de moeder.

14. Uiteraard zijn er ook andere, meer genuanceerde testamentaire mogelijkheden dan onterving. Zie voor een overzicht daarvan en de consequenties voor de legitieme portie (onder oud en huidig erfrecht) N.V.C.E. Bauduin, Testamenten voor mensen met een beperking, in het bijzonder een verstandelijke handicap, TE 2015, afl. 5, p. 102-108, W. Meijling, 'Gehandicapten' testament en het nieuwe erfrecht, WPNR 2005, afl. 6605-6606, p. 57-59 en p. 76-78, F.W.J.M. Schols, Het 'gunstig stemmen' van de kantonrechter. Enkele beschouwingen in het kader van de 'estate planning' bij aanwezigheid van een wegens geestelijke stoornis onder curatele gestelde legitimaris, De Notarisklerk 1996, afl. 1338, p. 68-71 en J.H. Linders, Erfrechtelijke verkrijging door en van een geestelijk gehandicapt kind, WPNR 1994, afl. 6142, p. 456-458. 
De kantonrechter is overigens niet gevoelig voor het argument dat de curanda de legitieme portie niet nodig heeft juist vanwege de toeslagen, of omdat de naasten wel zullen bijspringen als dat nodig is. De kantonrechter wijst de machtiging af omdat het niet te voorzien of te voorspellen is of na het overlijden van de moeder het toeslagensysteem als zodanig nog bestaat of mogelijk anders is ingericht, zodat de curanda haar legitieme portie mogelijk aanvullend nodig heeft om in haar levensonderhoud te kunnen blijven voorzien. Dat de erflater de onterving heeft gewild, maakt dat oordeel niet anders, aldus de kantonrechter onder 3.5.

Een juist eindoordeel, naar onze mening. In zijn motivering maakt de kantonrechter echter dezelfde soort fout als de Rotterdamse kantonrechter in paragraaf 4.1 door andere belangen af te wegen tegen die van het kwetsbare kind. Laat de Rotterdamse kantonrechter zich ten onrechte leiden door de testeervrijheid en de belangen van de langstlevende partner, in onderhavig geval overschrijdt de kantonrechter zijn taak door zich op te werpen als hoeder van het algemeen belang. ${ }^{15}$ De kantonrechter behoort zich in het licht van artikel 1:356 BW enkel en alleen te bekommeren om de vraag of het in het belang van het kwetsbare kind noodzakelijk, nuttig of wenselijk is om te berusten in een onterving. ${ }^{16}$ Alle omstandigheden van het geval, zowel materiële als niet-materiële, kunnen hierbij een rol spelen. Zo ook Van Emden, die als relevante omstandigheden onder meer het belang van de kwetsbare persoon bij goede familieverhoudingen, aandacht en geregeld bezoek benoemt. ${ }^{17}$ Houdt de kantonrechter om die reden rekening met het draagvlak voor zijn beslissing onder omstanders zoals familieleden, dan is nog altijd leidend het belang van de kwetsbare persoon zelf.

De belangen van derden kunnen leidend zijn als dat van het kwetsbare kind ontbreekt, zoals in de uitzonderlijke casus voor rechtbank Zutphen van 17 december 2012. ${ }^{18}$ Het onterfde gehandicapte kind in deze casus was terminaal ziek en had ruimschoots vermogen. De kantonrechter keurde de berusting in de onterving goed. Het kind werd daardoor niet geschaad in zijn (potentiële) belangen, terwijl zijn familie erbij gebaat was. Bij een langere levensverwachting is het belang van het kind bij zijn

15. Zie in deze zin W.M. Schrama \& F.M. de Kievit, PFT Updates, Commentaar PFR 2018-0032, laatst bijgewerkt op 3 februari 2020. Zie over deze problematiek ook A.J.H. Pleysier, Kantonrechter staat bewindvoerder toe af te zien van legitieme portie, JBN 2013/52. Zij merken overigens op dat zowel de kantonrechter als de curator over het hoofd ziet dat de niet-opeisbare vordering niet meetelt bij de beoordeling van de grondslag voor de huur- of zorgtoeslag. In meer algemene zin is deze uitspraak ook besproken in de Kroniek rechtspraak curatele, mentorschap en bewind, FJR 2019, afl. 3, p. 74 en 75.

16. Hoewel we het criterium 'in het belang van de minderjarige noodzakelijk, nuttig of wenselijk' bij de regeling van het meerderjarigenbewind niet terugvinden, is aannemelijk dat de kantonrechter hierbij eenzelfde maatstaf hanteert.

17. D. van Emden, Het kantongerechtstoezicht, WPNR 1996, afl. 6225, p. 399-400.

18. Notafax 2012/316, waarover A.J.H. Pleysier, Kantonrechter staat bewindvoerder toe af te zien van legitieme portie, JBN 2013/52. legitieme in beginsel gegeven, ook als het gaat om een voorlopig niet-opeisbare aanspraak.

\subsection{Hof's-Hertogenbosch 14 november 2019, ECII:NL:GHSHE:2019:4208}

Erflater laat bij zijn overlijden in 2017 een ongehuwde levenspartner en een zoon uit een eerdere relatie achter. Het kind is sinds zijn geboorte meervoudig complex gehandicapt. De zoon is onterfd en zijn legitieme portie is voorlopig niet opeisbaar (art. 4:82 BW).

Het vermogen van de gehandicapte zoon staat onder meerderjarigenbewind. De bewindvoerder verzoekt de kantonrechter machtiging om te berusten in de onterving, temeer omdat de legitieme portie pas opeisbaar is als de partner van erflater overlijdt. Daarmee zou volgens de bewindvoerder voldaan worden aan de uitdrukkelijke wens van vader, als verwoord in het testament. De kantonrechter wil hier niets van weten en verzoekt de bewindvoerder per omgaande namens de zoon een beroep te doen op diens legitieme portie.

De levenspartner gaat als erfgename en executeur in hoger beroep tegen de afwijzende beschikking van de kantonrechter. Volgens haar zal de zoon vanwege zijn handicap nooit in staat zijn om zelf te profiteren van enig bedrag dat hij door een beroep op de legitieme zou krijgen. De instelling waar de zoon verblijft, voorziet in het levensonderhoud of het wordt hem door de overheid verstrekt vanwege een Wajong-uitkering. Bovendien is een aanzienlijk geldbedrag ( $€ 25.000)$ voor de zoon gespaard, zodat hij de legitieme portie niet nodig zal hebben. Overigens zou de legitieme portie bij overlijden van de zoon weer vererven aan familieleden die zich nooit om hem bekommeren, en volgens de langstlevende zou dat juist tegen het belang van de zoon ingaan. Het inroepen van de legitieme portie zou ook betekenen dat erfbelasting verschuldigd is, die de langstlevende dan moet voorschieten, terwijl zij zelf nu juist een hoge vrijstelling geniet. De langstlevende geeft aan bereid te zijn via een op te richten stichting een bedrag van $€ 60.000$ ter beschikking te stellen voor het welzijn en de verzorging van de zoon. $\mathrm{Zij}$ voelt zich moreel verplicht om dit te doen en wil ook contact met de zoon blijven onderhouden, ongeacht de rechterlijke beslissing ten aanzien van de legitieme portie.

Het hof kan zich niet vinden in de stelling dat de zoon geen belang heeft bij zijn legitieme portie omdat hij feitelijk geen behoefte heeft aan geld. De zoon heeft reguliere uitgaven en het is niet te voorzien of hij in de toekomst nog geld nodig kan hebben voor bijvoorbeeld een hogere eigen bijdrage. Verder noemt het hof enkele voorbeelden van uitgaven buiten het reguliere kader, die het leven van de zoon kunnen veraangenamen. Zo zou mogelijk tegen betaling extra begeleiding en gezelschap kunnen worden aangetrokken.

Het hof erkent overigens dat, gelet op de lage levensverwachting van de zoon, zijn materiële financiële belang niet meteen ligt bij een voorlopig niet-opeisbare legi- 
tieme portie. Het hof voelt in deze uitzonderlijke situatie voor een op maat gemaakte oplossing. De zoon is het meest gebaat bij geld dat meteen beschikbaar is, en daarom heeft het hof oren naar het ongebruikelijke voorstel van de langstlevende. Het hof meent overigens wel dat, mede gezien de omvang van de legitieme portie, ten minste $€ 75.000$ door de langstlevende beschikbaar moet worden gesteld. Het hof verlangt een concreet plan van aanpak dat met alle betrokkenen wordt afgestemd en waarin actief wordt onderzocht hoe het (extra) geld kan bijdragen aan het welzijn van de zoon met concrete acties. De stichting en in het bijzonder het bestuur ervan moeten met voldoende waarborgen worden omkleed. Overlijdt de zoon, dan vloeit het overgebleven geld naar een ander fonds. Nadat aan het goedgekeurde plan uitvoering is gegeven, verleent het hof de verzochte machtiging om af te zien van de legitieme portie. ${ }^{19}$

Deze beschikking getuigt van een flexibele houding van alle betrokkenen en valt vanzelfsprekend toe te juichen. De omstandigheden van het geval spelen een voorname rol. Het belang van het kwetsbare kind staat voorop, maar dat hoeft niet per se te leiden tot het inroepen van de legitieme portie of juist het afzien daarvan. Het belang van het gestand doen van de uiterste wil van de testateur speelt in de overwegingen van het hof terecht geen rol. De legitieme portie is een recht waarop iedere legitimaris in weerwil van de uiterste wil aanspraak kan maken. Dat is voor een gehandicapt kind niet anders.

\section{Conclusie}

De kantonrechter heeft een niet te onderschatten taak de vermogensrechtelijke belangen van kwetsbare personen in het erfrecht te waarborgen. Dit geldt met name als het de rechtsverhouding betreft tussen de kwetsbare legitimaris en de langstlevende partner van de overledene. Niet zelden zal sprake zijn van een tegenstrijdig belang tussen beiden.

Schending van de legitieme blijft thans gemakkelijker onzichtbaar dan voor 2003, toen de legitieme nog goederenrechtelijk van aard was. Des te meer reden dat de toezichthoudende kantonrechter pal staat voor de kwetsbare legitimaris en diens legitieme. Niet alleen bij verzoeken om machtiging voor het berusten in de schending van de legitieme, maar ook bij verzoeken om machtiging voor het vaststellen van een erfrechtelijke (nietlegitimaire) vordering van het kind.

De kantonrechter dient in dat laatste geval niet alleen te bezien of die vordering correct is berekend. Hij hoort de rechtspositie van de kwetsbare legitimaris in de betreffende nalatenschap in zijn geheel te beschouwen. Als de kantonrechter bij de behandeling van het machtigingsverzoek terloops een schending van de legitieme portie

19. Hof 's-Hertogenbosch 6 februari 2020, ECLI:NL:GHSHE:2020:381 en Hof 's-Hertogenbosch 14 mei 2020, ECLI:NL:GHSHE:2020:1571. constateert, moet hij dit ambtshalve te berde brengen. Het maakt daarbij niet uit of sprake is van voortdurend toezicht, zoals bij de voogd, curator of meerderjarigenbewindvoerder het geval, dan wel van incidenteel toezicht op het bewind van een ouder. Bij incidenteel toezicht staat er voor de legitimaris in feite nog meer op het spel.

De kantonrechter hoeft zich bij zijn afwegingen aangaande de legitieme portie alleen te bekommeren om de belangen van de kwetsbare legitimaris. Zijn belang verdient, zolang de legitieme portie nog niet is afgeschaft, via de kantonrechter bescherming. ${ }^{20}$ Ook al staat het testament dankzij de testeervrijheid en de notaris als een huis en maakt de langstlevende partner geen misbruik van zijn erfrechtelijke bevoegdheden. Over andere belangen dan die van het kind - de testeervrijheid van erflater, het belang van de langstlevende of het publiek belang - hoeft de kantonrechter zich als zodanig niet te bekommeren. Daar heeft de wetgever ruimschoots in voorzien. Juist de kwetsbare legitimaris loopt zonder adequaat toezicht van de kantonrechter het gevaar dat zijn belangen worden geschaad. Die andere belangen kunnen het belang van het kind mede bepalen, maar nemen niet weg dat het belang van het kind zelf leidend blijft voor de kantonrechter.

De behandelde uitspraken laten zien dat elke situatie op haar eigen merites moet worden beoordeeld. Het belang van het kwetsbare kind dwingt niet per se tot het inroepen of het afzien van zijn legitieme portie. Het kan zijn dat het kind, bijvoorbeeld door zijn beperkte levensverwachting, immateriële belangen of testamentaire (straf)bepalingen, meer gebaat is bij een alternatieve maatwerkoplossing. Een bereidwillige opstelling van de langstlevende partner kan daarvoor een opening geven, zoals we zagen voor gerechtshof 's-Hertogenbosch (par. 5.2). Een kans die de rechter als belangenbehartiger met beide handen zal willen aanpakken.
20. Van afschaffing is voorlopig geen sprake, zo bleek recentelijk nog uit het antwoord van de Minister voor Rechtsbescherming op Kamervragen van Kamerlid Bergkamp (D66), Aanhangsel Handelingen II 2019/20, nr. 2922. 